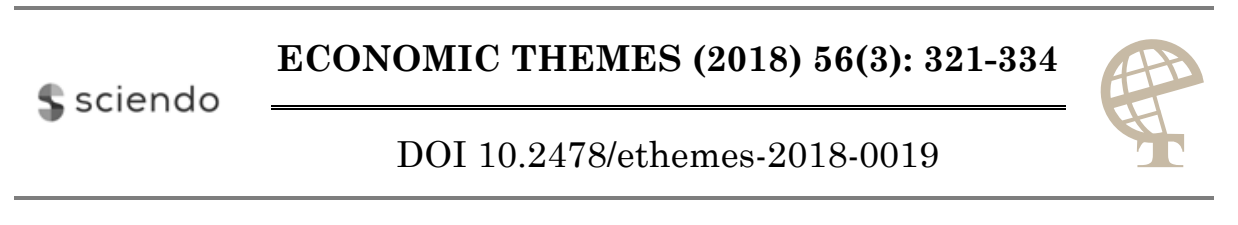

\title{
ENTERPRISE EFFICIENCY SOURCES IN THE CONTEMPORARY BUSINESS ENVIRONMENT
}

\author{
Violeta Domanović \\ University of Kragujevac, Faculty of Economics, Serbia \\ 凶vterzic@kg.ac.rs \\ Vesna Janjić \\ University of Kragujevac, Faculty of Economics, Serbia \\ $\bowtie$ vesnajanjic64@gmail.com \\ UDC \\ 65.015 .23 \\ Review \\ paper

\begin{abstract}
The issue of improving the efficiency of business operations is of particular importance in the conditions of modern business environment. For managers, the big challenge is how to achieve and to maintain, not to mention how to improve efficiency in a highly heterogeneous, complex, uncertain and unpredictable business environment. Significant sources of enterprise efficiency in a modern business environment are enterprise restructuring, business activities, as well an integrated approach to cost management, which is becoming an increasingly important determinant of business success and a source of competitive advantage. The paper provides an overview of theoretical and empirical research of the effects of certain sources on the performance of the enterprise. The conclusion is that only the complementary exploitation of all sources contributes to improving the efficiency of the enterprise in the long run.
\end{abstract}

Received: 12.08.2018

Accepted: 29.10.2018
Keywords: efficiency, restructuring, integrated cost management

JEL classification: M12, M21, O31

\section{Introduction}

The issue of providing, maintaining and improving the efficiency of business operations is of particular importance in the conditions of a modern business environment. This is because the modern business environment is complex, heterogeneous, dynamic and unpredictable. For managers, the big challenge is how to achieve and to retain, not to mention how to improve the efficiency of an 
enterprise's business. When it comes to improving efficiency, it refers to production efficiency (productivity), cost efficiency (cost-effectiveness) and efficiency of the use of enterprise's assets and capital (profitability). In other words, it is possible to talk about production efficiency (productivity and cost efficiency) and trade efficiency (profitability) (Grozdanović, Sekulić, 2006, 32). In this sense, managers undertake different measures of improvement of some partial expressions of efficiency (productivity, cost efficiency and profitability), and in particular profitability, as a comprehensive expression of the efficiency of the enterprise's operations. Implementation of profitability principle is done through increasing revenues, reducing costs, reducing assets and reorganizing business operations (Pokrajčić, 2002, 360-376). Hence, sources of efficiency are found in processes of adequate management of resources, which contribute to either increasing revenues or reducing costs, or both. If there is a high degree of complementarity between business activities and organizational units, profitability can be increased by reorganising business activities or by reorganising the enterprise (Pokrajčić, 2002, 371). Enterprise restructuring is done in order to increase efficiency both in terms of production and cost, and in order to increase the value for shareholders (Stančić, Čupić, 2017; Bowman, Singh, 1999). In addition to restructuring, cost efficiency is achieved through systematic total cost management (TCM). It is a systematic approach to cost management in all business segments (Hollmann, 2006). Cost management practices change with the change of business environment. There are new cost management models like Activity Based Costing (ABC), Target Costing (TC), Kaizen Costing (KC), Take-Back (TBC), Future Costing (FC). The features of the modern business environment simply force the managers to integrate various cost management models as well as to integrate them with the performance measurement models in order to improve the enterprise efficiency in the long term. In parallel with the changes in cost management practices, there was a change in the structure and focus of organizations. The process approach also included the inclusion of key trading partners, which resulted in the supply chains integration. The driving force of rapid changes is the buyer. Customer demands the products and services of better quality at lower prices, if possible, and with very fast delivery. The introduction and application of management innovations has become essential for the survival of an enterprise that is struggling to meet the challenges of the global market. However, their isolated application in the practice, apparently, has not been enough. This led to the numerous repetitions, gaps and misuse. Due to the lack of a holistic and systematic model, these managerial initiatives did not bring all desired outcomes. Integration of information is essential in order to optimally use the resources of the enterprise. The integration of a cost management model provides the basis for robust decision making because it provides multiple perspectives. Regardless of whether the enterprise is just beginning to implement new cost management models or the majority of its benefits, it is still necessary to integrate various cost management models as well cost management models with various performance management models. 
Hence, the subject of research is the efficiency improvement in modern business environment. The aim of the research is to indicate which sources of efficiency are dominant in the process of improving the performance of enterprises in a modern business environment. The starting hypothesis is that there are various sources of efficiency and that only by their complementary and integrated application, the enterprise can improve efficiency over a longer period of time. In order to test the starting hypothesis, a qualitative method was applied. The paper is structured into several sections. Firstly, theoretical considerations related to the concept of restructuring and the effects of the same on the performance of enterprises are given in the paper. Then, the paper points to the necessity of introducing and implementing an integrated approach to cost management. Finally, general conclusions regarding the sources of enterprise efficiency are made, as well as a concrete conclusion regarding the starting hypothesis. Research limitations were also identified, and future research directions were defined.

\section{Restructuring as a source of business efficiency}

An enterprise might apply four methods in order to improve its efficiency, especially the profitability. If the return on sale has been decreased over time or lower than average in the branch, then the managers make up decision to increase the sales in order to improve the profitability. The sales increase is possible by increasing the volume, price or both. Unfortunately, such a method of profitability improvement has not been always possible in the case the customers demand standardised products, if the product differentiation costs are higher than premium price and if there is a high price elasticity of demand. In a case of high price elasticity, the managers might choose the cost reduction in order to improve profitability. On the other side, if the coefficient of the total assets turnover or fixed assets turnover has been low over the time, the managers might decide to reduce the assets in order to improve the profitability. However, if there is a high degree of complementarity between business activities and organizational units, profitability can be increased by reorganising business activities or by reorganising the enterprise. This method would imply the revenue increase or cost reduction or both.

In contemporary business environment, because of ever changing customer needs and demands, technological changes, globalization and so on, enterprise restructuring has become the most useful way of the efficiency improvement in the long run. To be precise, the motive for enterprise restructuring is the efficiency improvement, but it does not always mean that the effects of the enterprise restructuring on the efficiency have been inevitably positive. Many research studies prove such a claim.

Lawrence (2015) points out that restructuring is desirable if the enterprise has poor competitiveness, but a very core business. Krstić (2012) points out that a strategic shift or an offensive restructuring strategy involves engaging in new 
product/market segments - the so-called product portfolio refresh. Savović (2018) points out that "corporate restructuring involves changes in the operational, financial, organizational, management structures of the enterprise in order to transform it and achieve greater value for its owners".

Girod and Whittington (2017) point out that "organizational restructuring involves changes in the fundamental principles of organizational design, for example, the transition from functional to divisional principles of organization". Restructuring could be defined as the process of adopting a set of managerial decisions and undertaking series of actions, which aim to achieve radical changes in the existing structure, strategy and position of enterprises (Stošić, 2015). Teece $(2007,1335)$ thinks that "reorganization is a key factor in achieving sustainable profitable growth and it implies recombining and reconfiguring assets and organizational structures as the enterprise grows and changes in the market and technology". Girod and Whittington (2017) point out two forms of organizational reorganisation: restructuring and reconfiguration. Restructuring implies a dominant, "but less frequent reorganization", while "reconfiguration implies a more continuous but limited reorganization". The authors compare effects of "organizational restructuring and organizational configuration" on performance. Generally, the authors find positive effects of restructuring, and the negative effects of reconfiguration. However, in a dynamic environment, the outcomes are the opposite. Namely, restructuring is less efficient in a dynamic environment, while reconfiguration is more effective, at least in terms of return on average assets (ROAA). Karim and Capron (2015) indicate that enterprise reconfiguration contributes to improving business efficiency by exploring new opportunities and innovation. Eisenhardt and Martin (2000) point out that restructuring is too episodic "in order to keep pace with changes in the environment".

Kim and Park (2016) believe that enterprise restructuring is one of the key tools for improving enterprise efficiency. The authors point out that external mechanisms have an important role in facilitating restructuring, and to the extent that, if there is resistance of insiders against restructuring, debtors and owners of capital can initiate or intensify restructuring activities. Chang (1996) notes that the size of the enterprise has a significant impact of the restructuring on the performance of enterprises, and so that large enterprises achieve better performance than small businesses. Bergh and Lim (2008) examine how the experience of the previous restructuring influences new decisions on restructuring and financial performance after restructuring. The authors find that previous experience and accumulated knowledge are relevant to sell-off, while organizational improvisation, which implies a short-term experience, better explains the separation of assets (spin-off).

The enterprise could restructure its activities in a number of ways. In many instances, restructuring involves deciding strategic managers to focus on their primary business/jobs after they make sales, isolating one business unit, liquidating, reengineering, or releasing a number of employees. One of the possible 
strategic directions that an enterprise can undertake is the sale of one or more business units. Often, when an enterprise finds that one business unit does not deliver the expected results or does not fit into the long-term direction or plans of an enterprise, strategic managers decide to sell it. This process of selling one job to someone to whom it will become an integral part of a business life is called the release/deprivation of part of the assets of the enterprise. The business could be sold to independent investors, other companies, or the management of a business unit that is subject to release. Another possibility for enterprise restructuring is the removal of one business unit by its isolation.

The last option that is being considered for restructuring the enterprise is bankruptcy. This is typically the result of a long-standing decline in the level of enterprise results that could not mitigate or partially mitigate the aforementioned options for restructuring or cost reduction because they were not effectively implemented. Many companies that are facing the need to withdraw or seriously restructure (necessary for turning) will look at a coordinated long-term programme of strategic actions. Strategic managers may decide to reduce costs or undertake restructuring actions (such as releasing separate business units or reengineering work processes in some areas) even during organizational growth if it also contributes to the development of an enterprise or the exploitation of its competitive advantage. The key question, therefore, is whether these actions increase or strengthen the competitive advantage of the enterprise. The question arises what if there is no customer for a business unit or there is no possibility to allocate a business unit. The only solution in this case is liquidation, which completely closes the business. Liquidation is the last solution that is adopted if the turning strategy does not give the desired effect.

Cost reduction could be undertaken at the whole enterprise level or selectively. Strategic managers perform valuation to see if there are some failures, repetitions, or inefficiencies in work tasks and activities (that is, in organizational capacity) that could be eliminated. In addition, they see if certain resources could be eliminated or more efficiently used. In general, strategic managers will have to think about reducing and eliminating certain work tasks and activities or almost entire departments, units or divisions. If the enterprise finds that the results in any business units or areas do not meet standards and do not meet the strategic goals, it is desirable to completely change the way of thinking and how it works. This change of fundamental thinking and radical redesign of organizational business processes is reengineering. This involves reexamining traditional assumptions and approaches, as well as radically redesigning and changing organizational work activities. In the reengineering process, current resources, skills, and core competencies are irrelevant because strategic managers are trying to find out if work processes can be somehow better designed. Therefore, this process involves radical and often drastic changes. However, every enterprise does not succeed in making the necessary analysis and not everyone is ready enough to make drastic changes. 


\section{An integrated cost management model as a source of business efficiency}

The key to achieving profitable performance is reflected in the understanding of the relationship between activity, outcome, and value creation. To that end, the enterprise must "integrate its information flows". Information integration makes possible to create a "knowledge base that could be used to communicate decisions, tasks, results, and capabilities from the top to down" (Stenzel, Stenzel, 2003, 16). Integrating information between all functions and processes is essential for effective management in a dynamic and turbulent global economy. Cost and performance management systems seek to present information relevant to decision-making and to report on the process of achieving objectives. Managers focus on cost and performance information to help coordinate activities, especially in relation to larger environments. Decision makers rely on insights into costs and performance to cognitively colour the image of themselves, their organizations and the environment (Stenzel, Stenzel, 2003, 16). The "key principles of the Integrated Cost Management System (ICMS)" express the managers' needs. Specifically, these principles include (Statement on Management Accounting, 2000, 2): "strategic orientation, customer requirements, orientation to value, focus on process/horizontal focus, relevance to decision-making, cost efficiency, relationship-based cost management system".

ICMS highlights the relationships "between information flows and decisions at different levels in the organization" (Statement on Management Accounting, 2000). It implies the identification of relevant data and information that must be diffused among "individuals, teams, departments, processes, and entities for effective, coordinated decision-making and action" (Statement on Management Accounting, 2000). The key idea of ICMS is that the realization of "profitable performance and competitive advantage stems from a deeper understanding of the relationships between activities, outcomes and value creation" (Statement on Management Accounting, 2000).

Another main idea is that the "integration of information flows" is a fundamental component of "effective decision making", which enables communication and strengthens connections between mutually dependent functions, teams or entities. ICMS includes the following elements (Statement on Management Accounting, 2000): "Strategic Management Processes - these processes include current best practices such as cost management, asset management, cost management, process management, an enterprise as part of the supply chain, integrated performance management and cost-based management; Decision domains - customer / market, product, process, and resource level; Integration - which implies integration of data and information with key strategic management processes".

Kaličanin and Knežević (2013) discuss activity-based costing as an information basis for an efficient strategic management process. The authors point out that activity-based costing enables cost recording, cost analysis and management, 
which contributes to the better operating and strategic business decisions. Finally, this leads to the improved efficiency in the long term. Also, the authors consider that cost management model, such as activity-based costing, is complementary and might be integrated into the strategic management model, such as the Balanced Scorecard model is. Namely, the information gathered from activity-based costing might be included into the perspectives in the Balanced Scorecard model. This is especially the case in the perspective of internal business process, since the business processes are consisted of the more activities, which are the key notion in the activity-based costing. The $\mathrm{ABC}$ system "provides and information basis for permanent cost reduction at all levels of the company" (Kaličanin and Knežević, 2013, 112).

Thus, an integrated performance management is a key grummet between the plan and the outcomes. Current actions from different areas of the enterprise must be merged into a coherent whole. It is here that combines process management and activity-based management. Process management accentuates the "horizontal connections of activities, starting from managing core workflows through the integration of processes and jobs" (Statement on Management Accounting, 2000). It connects organizational actions with customer values. Similarly, activity-based management highlights an "efficient combination of resources in order to create unique organizational skills" (Statement on Management Accounting, 2000). It analyses the concrete actions and their linkage with "processes, costs, performance, and results". Activity-based management removes a gap by providing information on costs and business activities from the process point of view. Also, activity-based management makes a valid information base for managers' decision making so it accentuates the opportunity costs and value analysis.

A successful cost management, through overcoming cost efficiency and improving the overall performance of the enterprise, therefore requires an adequate management-information support. In order to create such a support, it is not enough only to implement and apply individual, isolated modern accounting approaches and cost management concepts, but it is more necessary to integrate more of them within the product life cycle and beyond, within the overall value chain. This is further encouraged by significant savings in costs that are realised as a synergetic effect of an adequate combination of different approaches and management concepts and cost accounting. Integrated application of modern approaches and cost management concepts, in particular Activity Based Costing (ABC), Target Costing (TC), Kaizen Costing (KC), Take-Back (TBC), Future Costing (FC) as extremely valuable analytical-methodological cost management tools, excellent results can be achieved in terms of cost reduction at all stages of the product life cycle and in the value chain.

Without going into the deeper elaboration of the meaning of the approach and management concepts and cost accounting, it seems that an attempt to integrate their use can contribute to the achievement of numerous benefits. For example, 
action-oriented kaizen provides the possibility of a common application with the $\mathrm{ABC}$ concept in a traditional or modified form. The integrated application of KC and $\mathrm{ABC}$ would imply the application of the kaizen concept to the activities identified in the application of the $\mathrm{ABC}$ concept, in particular to the activities of unnecessary spending that are not in the function of creating values, which would thus represent an important basis for cost reduction. The use of kaizen techniques to reduce costs of defined activities would enable cost savings in the production phase, as well as adequate product quality. Significant effects can also be achieved by the integrated use of the modified form of ABC, i.e. Future Costing and Kaizen Costing, especially subject-specific cost calculation, which aims to harmonize the relationship between product characteristics, the cost of their security and selling prices (Janjić, Todorović, Jovanović, 2012) .

Especially suitable for aggressive cost management throughout the life cycle of products are Target Costing and Kaizen Costing, as evidenced by theoretical considerations and their practical application. These two accounting concepts form a powerful and complete system for cost reduction, where the results of one system behave as the input elements of the other, thereby increasing the effectiveness of the overall cost management programme (Malinić, Janjić, 2011).

Janjić, Karapavlović and Damjanović (2017) examine in what extent the techniques of strategic cost management such as "value-chain, activity-based costing, balanced scorecard, kaizen costing and target costing" - are applicable in the enterprises in the Republic of Serbia. The authors conclud that the accountants in the Republic of Serbia are aware of the significance of these concepts, but are not well educated to implement them in the right way. This is the case for all enterprises no matter of their size, business activity, legal form or net profit/net loss.

Mijoč et al. (2014) investigated whether the integration of modern cost management models, such as target costing, activity-based costing and total quality management affect the enterprise's financial performances in Croatia. The authors proved that target costing and activity-based costing do not contribute to the financial performance improvement, separately. On the other side, the authors claim, but not with certainty, that total quality management better affect the financial performance. Also, the authors do not claim with the certainty whether the integrated application of these cost management models affect the financial performances.

Al-Halabi and Shaqqour (2018) examine the influence of activity-based costing on enterprise's efficiency in Jordan. The authors conclude that activity-based costing has a great impact on managing resources, efficiency, cost reduction and costs of unused capacity. This is the case not only for the enterprise itself, but rather for all members in the value chain and supply chain. 
Dwivedi and Chakraborty (2016) discuss the possibility of integration cost management model, such as activity-based costing, and performance measurement model, such as balanced scorecard model. They explain how it is possible to integrate them in case of thermal power plant. They proved that these management innovations altogether make better budget allocation and resource planning, as well as efficiency improvement since internal cost minimization could be achieved.

Sharaf-Addin, Omar and Sulaiman (2016) investigate whether it is possible to integrate target costing (TC), as a cost management model, with the balanced scorecard (BSC), as a performance management model. They examined this in the case of Malaysian automotive industry. They found that the "BSC model could be a supportive tool for the TC success". This means that the four elements of Target Costing - "cost reduction, quality, functionality and lead time" - could be incorporated in the right way into the main four perspectives in the Balanced Scorecard model, respectively - finance, customer, internal business processes and learning and growth. The authors, also, take into account the type of industry and type of strategy, i.e. whether the enterprise adopted the "confrontation strategy" or "non-confrontation strategy such as cost leadership or differentiation strategy".

\section{Conclusion}

The enterprise's efficiency sources have a dynamic character and are subject to change in accordance with the changes and tendencies of the business environment. In a modern business environment, it is a real challenge to maintain, not to speak of improving the efficiency of the enterprise.

If there is a high degree of complementarity between business activities and organizational units, profitability, as the most important expression of enterprise efficiency, could be increased by reorganizing business activities or by reorganizing the enterprise. A significant source of business efficiency is the total cost management (TCM). It is a systematic approach to cost management in all business segments. Cost management practices change with the change of business environment. New measurement and costing systems have been developed separately, so it led to the numerous repetitions, gaps and misuse. Thus, it is necessary to integrate different cost management initiatives as well as to integrate cost management initiatives with other management innovations, such as integrated and holistic performance management models. Each observed efficiency source might have positive or negative effect on efficiency of the enterprise in the long term. Only integrated and complementary application of alternative efficiency sources might lead to the positive effects on the enterprise efficiency in the long term.

However, it is hard to simply say that integration will inevitably leads to the enterprise's efficiency improvement. It is possible to claim with higher certainty that the integrated application of cost management models as well as integration of 
cost management models with performance management models would contribute to better performance and efficiency improvement in the long term. There are alternative sources of efficiency in the modern business environment. But, cost management certainly takes the key role in the strategic and operating business decisions. Otherwise, cost management is also the segment of the corporate restructuring. Corporate restructuring, itself, might imply the cost reduction, which is the mere heart of cost management.

However, the research is subject to some limitations. Namely, here is the theoretical research based on the theoretical and empirical research of other authors. In future, it would be useful to make cross-sectional and longitudinal study on efficiency sources, so that it would be possible to derive the similarities and differences about the efficiency sources in diversified sample in a long-term period.

\section{Acknowledgements}

This paper is a part of the interdisciplinary research Project (No. 41010), which is funded by the Ministry of Education, Science and Technological Development of the Republic of Serbia.

\section{References}

Al-Halabi, B. N., Shaqqour, F. O. (2018). The effect of activity-based costing (ABC) on managing the efficiency of performance in Jordanian manufacturing corporations - an analytical study. Accounting and Finance Research, 7(1), 262-271, http://afr.sciedupress.com.

Bergh, D. D., Ngah-Kiing Lim, E. (2008) Learning how to restructure: absorptive capacity and improvisational views of restructuring actions and performance. Strategic Management Journal, 29(6), 593-616. DOI: 10.1002/smj.676.

Bowman, E. H., Singh, H., Useem, M., Bhadury, R. (1999) When does restructuring improve economic performance? California Management Review, 41(2), 33-54.

Calvo-Mora, A., Navarro-García, A., Rey-Moreno, M. (2016) Excellence management practices, knowledge management and key business results in large organisations and SMEs: A multi-group analysis. European Management Journal, 34, 661-673, http://dx.doi.org/10.1016/j.emj.2016.06.005.

Chang, J. S. (1996) An evolutionary perspective on diversification and corporate restructuring: entry, exit, and economic performance during 1981-89. Strategic Management Journal, Vol. 17(8), 587-611.

Chatzoudes, D., Chatzoglou, P., Vraimaki, E. (2015) The central role of knowledge management in business operations: Developing a new conceptual framework. Business Process Management Journal, 21(5), 1117-1139, doi: 10.1108/BPMJ-10-2014-0099.

Chen. C.-J., Huang, J.-W. (2009) Strategic human resource practices and innovation performance - the mediating role of knowledge management capacity. Journal of Business Research, 62, 104-114, doi:10.1016/j.jbusres.2007.11.016.

Chevallier, C., Laarraf, Z., Lacam, J. S., Miloudi, A., Salvetat, D. (2016) Competitive intelligence, knowledge management and competition: The case of European hightechnology firms. Business Process Management Journal, 22(6), 1192-1211, http://doi.org/10.1108/BPMJ-11-2015-0161. 
Choi, B., Poon, K. S., Davis, G. J. (2006) Effects of knowledge management strategy on organizational performance: a complementarity theory-based approach. The International Journal of Management Science, 36, 235-251, Available online at www.sciencedirect.com, doi:10.1016/j.omega.2006.06.007.

Davenport, T. H., Prusak, L. (1998) Working knowledge: how organizations manage what they know. Harvard Business School Press. Retrieved January 12, 2013, from: http://www.acm.org/ubiquity/book/t_davenport_l.html.

Davenport, T. H., Volpel, S. C. (2001) The rise of knowledge towards attention management. Journal of Knowledge Management, 5(3), 212-221.

Dwivedi, R., Chakraborty, S. (2016) Development of a strategic management tool in a thermal power plant using ABC and BSC models. Serbian Journal of Management, 11(1), 8197.

Eisenhardt, K. M., Martin, J. A. (2000) Dynamic capabilities: what are they? Strategic Management Journal, 21 (10/11): 1105-1121.

Erden, Z., Klang, D., Sydler, R., von Krogh, G. (2014) Knowledge-flows and firm performance. Journal of Business Research, 67, 2777-2785, http://dx.doi.org/10.1016/j.jbusres.2012.09.001.

Forghani, M. A., Tavasoli, A. (2017) Investigating the relationship between knowledge management dimensions and organizational performance in lean manufacturing. International Journal of Management, Accounting and Economics, 4(3), 218-226.

Fugate, S. B., Stank, P. T. I Mentzer, T. J. (2009) Linking improved knowledge management to operational and organizational performance. Journal of Operations Management, 27, 247-264, doi:10.1016/j.jom.2008.09.003.

Gibbs, P. A. (1993) Determinants of corporate restructuring: The relative importance of corporate governance, takeover threat, and free cash flow. Strategic Management Journal 14(S1), 51-68.

Girod, J. G. S., Whittington, R. (2017) Reconfiguration, restructuring and firm performance: dynamic capabilities and environmental dynamism. Strategic Management Journal, 38(5), 1121-1133. DOI: 10.1002/smj.2543.

Grozdanović, D., Sekulić, V. (2006) Ekonomika preduzeća. Kragujevac: Ekonomski fakultet Univerziteta u Kragujevcu.

Gupta, B., Iyer, S. L., Aronson, E. J. (2000) Knowledge management: practices and challenges. Industrial Management and Data Systems, February, 100(1), 1-14, doi: 10.1108/02635570010273018.

Hollmann, K. J. (ed.) (2006). Total cost management framework: an integrated approach to portfolio, program and project management. AACE International.

Janjić, V., Todorović, M., Jovanović, D. (2012) Koncepti i sistemi integrisane računovodstvene podrške upravljanju troškovima u fazi proizvodnje. U: Marković, D., Vuksanović, E., Stefanović, R., Ljubisavljević, S., (eds.), Finansije $i$ računovodstvo u funkciji privrednog rasta: 215-237. Kragujevac: Ekonomski fakultet Univerziteta u Kragujevcu.

Janjić, V., Karapavlović, N., Damjanović, J. (2017) Techniques of strategic cost management the case of Serbia. Teme, XLI, No. 2, 441-455, DOI: 10.22190/TEME1702441J.

Kaličanin, Đ., Knežević, V. (2013). Activity-based Costing as an information basis for an efficient strategic management process. Economic Annals, Volume LVIII, No. 197/April-June, 95-119. 
Karim, S., Capron, L. (2015) Reconfiguration: Adding, Redeploying, Recombining and Divesting Resources and Business Units. Strategic Management Journal, 37(13), https://doi.org/10.1002/smj.2537

Kiessling, T., Richey, R. G., Meng, J., Dabic, M. (2009) Exploring knowledge management to organizational performance outcomes in a transition economy. Journal of World Business, 44, 421-433, doi: 10.1016/j.jwb.2008.11.006.

Kim, B.-Y., Park, J. (2016) Financial systems and enterprise restructuring in Eastern Europe. Eastern European Economics, 54(6), 503-520. DOI: 10.1080/00128775. 2016.1215229 .

Krstić, B. (2012) Uloga strategijske kontrole u unapređenju poslovnih performansi. Niš: Ekonomski fakultet.

Lawrence, W. W. (2015) Turnaround strategies for business recovery from decline. Journal of Eastern Caribbean Studies, 40(1), 165-178.

Lee, H., Choi, B. (2003) Knowledge management enablers, processes, and organizational performance: an integrative view and empirical examination. Journal of Management Information Systems, Summer, 20(1), 179-228.

Lyu, H., Zhou, Z., Znahg, Z. (2016) Measuring knowledge management performance in organizations: an integrative framework of balanced scorecard and fuzzy evaluation. Information www.mdpi.com/journal/information, 7, 29; doi: 10.3390/info7020029, pp. $1-11$.

Mijoč, J., Starčević Pekanov, D., Mijoč, I. (2014). Investigation of the relationship between contemporary cost management methods and improvement in financial performance. Economic Research-Ekonomska Istraživanja, 27:1, 393-413, DOI: 10.1080/1331677X.2014.966970.

Noruzy, A., Dalfard, M. V., Azdhadari, B., Nazari-Shirkouhi, S. and Rezazadeh, A. (2013) Relations between transformational leadership, organizational learning, knowledge management, organizational innovation, and organizational performance: an empirical investigation of manufacturing firms. International Journal of Advanced Manufacturing Technology, 64, 1073-1085, doi:101007/s00170-012-4038-y.

OECD (1996) The knowledge-based economy. Available online: http://www.oecd.org/sti/scitech/theknowledge-basedeconomy.htm. Taken 19.10.2017.

Pokrajčíc, D. (2002) Ekonomika preduzeća. Beograd: Čigoja štampa.

Savović, S. (2018) Izazovi upravljanja integracionim procesima preduzeća. Kragujevac: Ekonomski fakultet Univerziteta u Kragujevcu.

Sharaf-Addin, H. H., Omar, N., Sulaiman, S. (2016) Integrating target costing indicators within the balanced scorecard model in Malaysian automotive industry: a Rasch analysis. International Journal of Social Science and Economic Research, Vol. 01, No. 10, 15411565, https://www.researchgate.net/publication/310451653.

Slavković, M., Babić, V. (2013) Knowledge management, innovativeness, and organizational performance: evidence from Serbia. Economic Annals, LVIII(199), 85-107, doi: 10.2298/EKA13990855.

Stančić, P., Čupić, M. (2017) Finansijski efekti restrukturiranja preduzeća u Šumadiji i Pomoravlju. U Veselinović, P., Makojević, N. i Slavković, M. (redaktori) Uticaj globalizacije na poslovno upravljanje i ekonomski razvoj Šumadije i Pomoravlja. Kragujevac: Ekonomski fakultet Univerziteta u Kragujevcu, 319-330.

Statements on Management Accounting (2000) Designing an integrated cost management system for driving profit and organizational performance. Institute of Management Accountants. www.imanet.org. 
Stenzel, C., Stenzel, J. (2003) From cost to performance management - a blueprint for organizational development. John Wiley\&Sons.

Stošić, I. (2015) Restrukturiranje preduzeća kao pretpostavka ekonomskog razvoja Srbije. U: Strukturne promene u Srbiji - dosadašnji rezultati i perspektive. Institut ekonomskih nauka, Beograd, pp. 247-265. ISBN 978-86-89465-17-4. http://ebooks.ien.bg.ac.rs/27/1/is_2015_01.pdf.

Teece, D. J. (2007) Explicating dynamic capabilities: the nature and micro foundations of sustainable enterprise performance. Strategic Management Journal, 28 (13), 13191350. DOI: $10.1002 /$ smj.640.

Wong, K. Y., Aspinwall, E. (2005) An empirical study of the important factors for knowledge management adoption in the SME sector. Journal of Knowledge Management, 9(3), 6482.

Malinić, S., Janjić, V. (2011) Integrated Application of Contemporary Systems of cost accounting and Cost management, In Babić, V. (Ed.), Contemporary Issues in Economics, Business and Management: 377-383. Kragujevac: Faculty of Economics.

\section{IZVORI EFIKASNOSTI POSLOVANJA PREDUZEĆA U SAVREMENOM POSLOVNOM OKRUŽENJU}

Apstrakt: Pitanje unapređenja efikasnosti poslovanja preduzeća od posebnog je značaja u uslovima savremenog poslovnog okruženja. Za menadžere, veliki izazov je kako postići i zadržati, a da se ne govori o unapređenju efikasnosti u izrazito heterogenom, kompleksnom, neizvesnom i nepredvidivom poslovnom okruženju. Značajni izvori efikasnosti preduzeća u savremenom poslovnom okruženju su restrukturiranje preduzeća i poslovnih aktivnosti i integrisani pristup upravljanju troškovima, koji postaju sve značajnija determinanta poslovnog uspeha i izvor konkurentske prednosti. U radu se daje pregled teorijskih i empirijskih istraživanja efekata pojedinih izvora na performanse preduzeća. Zaključak je da samo komplementarna eksploatacija svih izvora doprinosi unapređenju efikasnosti preduzeća u dugom roku.

Ključne reči: efikasnost, restrukturiranje, integrisano upravljanje troškovima.

\section{Authors' biographies}

Violeta Domanović has been employed at the Faculty of Economics, University of Kragujevac, since 1997. She received her PhD degree, at the Faculty of Economics, University of Belgrade, in the field of business economics. She was appointed as an Associate Professor in 2014, at the Faculty of Economics, University of Kragujevac. Her main fields of interest and research are the following: performance measurement and cost management. She teaches courses at the undergraduate level - Business Economics as well as Master course - Performance measurement and control systems. She is a member of the Society of Economists in Kragujevac. 
Vesna Janjić has been employed at the Faculty of Economics, University of Kragujevac, since 1991. She received her $\mathrm{PhD}$ degree, at the Faculty of Economics, University of Kragujevac, in the field of management accounting. She was appointed as an Associate Professor in 2015, at the Faculty of Economics, University of Kragujevac. Her main fields of interest and research are the following: contemporary methodological approaches to cost accounting, cost and performance management. She teaches courses at the undergraduate level - Management Accounting and Cost Accounting, as well as Master course - Strategic Management Accounting and Budgeting and Control and PhD course - Integrated Cost Management. She is a member of the Society of Economists in Kragujevac. 